\title{
THE IMPACT OF COVID -19 PANDEMIC ON THE ECONOMIC GROWTH IN BANGLADESH: A CONCEPTUAL REVIEW
}

\author{
Md. Shahbub Alam \\ Lecturer \\ Faculty of Business Administration \\ Islamic University, Kusthia, Bangladesh \\ E-mail: shahbub.ais07@gmail.com \\ Md. Jafor Ali \\ Lecturer \\ Faculty of Business Administration \\ Islamic University, Kusthia, Bangladesh \\ E-mail: jaforkb@gmail.com \\ Dr. Abul Bashar Bhuiyan \\ Associate Professor \\ Faculty of Business and Accountancy \\ University of Selangor, Shah Alam, Malaysia \\ E-mail: bashariuk@gmail.com

\section{Dr. Mohammad Solaiman} \\ Associate Professor \\ Department of Marketing \\ Comilla University, Cumilla, Bangladesh \\ E-mail: solaimanmktgcou@yahoo.com

\section{Dr. Mohammad Abdur Rahman \\ Assistant Professor} \\ School of Business Administration \\ Faculty of Business and Entrepreneurship \\ Daffodil International University, Dhaka, Bangladesh \\ E-mail: rahman@diu.edu.bd
}

\begin{abstract}
Since the outburst of Covid-19 in China, the world economy is passing in a turmoil situation. Undeniably the economy of Bangladesh is also grappled by the severe public health crisis of the Covid-19. As the public health emergency is heavily interconnected with economic affairs, it has impacted each of the pillars of the economy of Bangladesh. The main purpose of this paper is to make evaluations of the potential impact of the COVID-19 pandemic on the economy of Bangladesh. This study is based on an empirical review of the recent study works, reports, working papers of home, and abroad regarding economic crisis. The review findings of the paper revealed that the COVID-19 pandemic have significant impacts on the different indicators
\end{abstract}


of the economy of Bangladesh especially, Readymade Garments Sector, Foreign Remittance, Bank and Financial Institutions, Food and Agricultures, Local Trade, Foreign Trade (Export and Import), GDP (Gross Domestic Product), SDGs (Sustainable Development Goal), Government Revenue and Employment etc. This study suggested that as Covid-19 still surfacing all over the world so some steps should be ensured by the government agencies of Bangladesh to mitigate possible threats for the economy.

Keywords: Covid-19, Impact, Economy of Bangladesh, SDGs.

\section{INTRODUCTION}

The novel coronavirus disease that was first reported in Wuhan, China in December 2019 (COVID-19) is quickly spreading around the world. As of March 27, 2020, the total number of cases exceeds 460,000 and the disease has claimed more than 20,000 lives globally. Since March 2020, while new cases in China appear to have settled down, the number of cases is exponentially growing in the rest of the world(Toda, 2020). The 20th century witnessed two pandemics since the historic 'Spanish Influenza' of 1918: the 'Asian flu' of 1957 and the 'Hong Kong flu' of 1968. The 21st century has seen four pandemic outbreaks: N1H1 in 2009 ('bird flu'), Severe Acute Respiratory Syndrome (SARS) in 2002, Middle East Respiratory Syndrome (MERS) in 2012, and Ebola which peaked in 2013-14. But this COVID-19 pandemic is different, economically speaking hit nations both economically dominant nations as well as economically dependent nations. The number of COVID-19 case is already many fold larger than the number of SARS cases in the previous pandemic(Baldwin et al., n.d.). This already focused on that COVID-19 is spreading human suffering worldwide. As the public health crisis is highly associated with economic affairs as like as global public health, economy, and livelihood issues, it has grappled the global economy exponentially towards the dramatic downturn that pushed it into the worst recession after the great depression of the 1930s (Ali, Bhuiyan, Zulkifli, \& Hassan, 2020). It is most definitely spreading economic suffering worldwide. The virus may be as contagious economically as it is medically(Baldwin et al., n.d.). The potential impact of COVID19 on global monetary poverty through per capita household income or consumption contraction. The impact will spread on among low, medium, and high-income people(Sumner et al., 2020). The other influential discussions over monetary and fiscal policy responses to the COVID-19 epidemic and the ensuing economic fallout (Guerrieri et al., 2020).

The looming economic crisis may create panic, mass unemployment, poverty, and homelessness. The US already claimed a vast increase in unemployment (4.6 million) during the coronavirus emergency and speculated that lockdown will cause more deaths than COVID-19 itself amid the recession (Reger et al., 2020). The coronavirus disease (COVID-19) has critically impacted global health systems and economies, especially in developing countries. Those countries have been struggling to address the preexisting burden of diseases with limited resources, which will become even more challenging during COVID-19. The economic implications related to COVID-19 in those countries include a high cost of care, market failures in pluralistic health systems, high out-of-pocket expenses, the added burden of noncommunicable diseases, missed economic opportunities, and socioeconomic consequences like unemployment and poverty (Rodela et al., 2020). The global pandemic has also made an impact on the overpopulated developing country Bangladesh. In Bangladesh, the Institute of Epidemiology, Disease Control and Research (IEDCR) has reported the first 3 cases of 
coronavirus on 8 March 2020. Currently, the country has a total of 3,37,520 coronavirus cases with 4,733 deaths (September 14, 2020)(IEDCR).

To combat, Bangladesh has employed international travel bans and a gradual lockdown. However, countries like Bangladesh are at a greater risk because of large population density, inadequate infrastructure, and healthcare systems to provide the required support(Ma et al., 2020). Bangladesh is one of the most vulnerable countries due to high population density (170 million people in 147,000 sq.km), poor health care systems, and a weak economy. In recent years, Bangladesh's economy has been growing well with a GDP growth rate of more than $7.5 \%$, however, $20 \%$ of the population is poor. Nevertheless, because of the rapid spread of the COVID-19, Bangladesh's economy has already started taking a big hit. The nationwide shutdown has already suspended almost all economic activities except agriculture and made thousands of employments at risk. International trade orders, especially in ready-made garments industries, are being greatly canceled (M. T. Islam et al., 2020). Most of the people in our country live below the poverty line. Due to lockdown since March 8, 2020, the people are passing an overwhelmingly stressful moment. If the lockdown process continues for longer many people would face severe starvation. The economic strength of the country is also deteriorating day by day. The rate of unemployment increases day by day. Though govt. takes initiatives to tackle these pandemic situations by various promotional packages to the entrepreneur, but the recent situation has not improved so much because of banning international trade. Our most promising export sectors e.g. labor; garments, fish, etc. are passing hazardous moments.

In such circumstances, this paper tries to summarizes of available resources to review of possible impacts of Covid 19 on the economic indicators in Bangladesh, especially readymade garments, foreign remittance, local trade, international trade, government revenue, employment, financial institutions, production, and distributions due to the isolation, quarantine, distancing, and shutdown measures. Therefore, the main purpose of this study is to make review and evaluations of the potential impact of COVID-19 on the economy of Bangladesh.

\section{Concept of The COVID -19 Pandemic}

\section{BACKGROUND OF THE STUDY}

Since December, 2019, a novel coronavirus disease 2 (SARS-Cov-2) known as COVID-19, a group of acute respiratory diseases with never disclosed and unknown etiology, was first identified in 1 man in Wuhan, the capital of the Hubei Province in the People's Republic of China The novel coronavirus disease that was first reported in Wuhan, China in December 2019 (COVID-19) is quickly spreading around the world. As of March 27, 2020, the total number of cases exceeds 460,000 and the disease has claimed more than 20,000 lives globally. Since March 2020, while new cases in China appear to have settled down, the number of cases is exponentially growing in the rest of the world(Toda, 2020). The 20th century witnessed two pandemics since the historic 'Spanish Influenza' of 1918: the 'Asian flu' of 1957 and the 'Hong Kong flu' of 1968. The 21st century has seen four pandemic outbreaks: N1H1 in 2009 ('bird flu'), Severe Acute Respiratory Syndrome (SARS) in 2002, Middle East Respiratory Syndrome (MERS) in 2012, and Ebola which peaked in 2013-14. But this COVID-19 pandemic is different, economically speaking hit nations both economically dominant nations as well as economically dependent nations.

However, the number of COVID-19 case is already many fold larger than the number of SARS cases in the previous pandemic(Baldwin et al., n.d.). This already focused on that COVID-19 is spreading human suffering worldwide. As the public health crisis is highly 
associated with economic affairs as like as global public health, economy, and livelihood issues, it has grappled the global economy exponentially towards the dramatic downturn that pushed it into the worst recession after the great depression of the 1930s (Ali, Bhuiyan, \& Zulkifli), It is most definitely spreading economic suffering worldwide. The virus may be as contagious economically as it is medically (Baldwin et al., n.d.). The potential impact of COVID-19 on global monetary poverty through per capita household income or consumption contraction. The impact will spread on among low, medium, and high-income people(Sumner et al., 2020). The other influential discussions over monetary and fiscal policy responses to the COVID-19 epidemic and the ensuing economic fallout (Guerrieri et al., 2020).

\section{The COVID -19 Pandemic and Interconnected Global Economy}

Since the Covid-19 epidemic outraises, there has affected millions of people and claimed the lives of more than three hundred thousand people around the world. Likewise, the current Covid19 epidemic has affected all walks of life and businesses in several ways, including a sharp drop in domestic demand, supply disruptions, a reduction in tourism and travel. scarcity of trade and production and impacts on health (Abiad et al., 2020; Hutt, 2020; Report, 2020). Even the pandemic has become the primary concern for the survival of humanity in the world. While the devastation of the Covid-19 pandemic is still elusive, defeating this pandemic requires coordinated and coordinated efforts globally to build a resilient and sustainable public health system and an economic system to recover. As international interdependence has flourished, leading indicative acts such as agriculture, economy, education, energy, environment, sociopolitics, health, infrastructure, politics international, population and human development, etc. interact to ensure sustainable and inclusive growth for a shared experience and vision of prosperity among states. No state alone can achieve sustainable human and social development in this era of globalization. Amid the significant public health risk COVID-19 poses to the world, the World Health Organization (WHO) has declared a public health emergency of international concern to coordinate international responses to the disease.

However, it is certainly a global crisis because no country is immune to this health and economic disaster. Among the interconnected indicators, the episode of global health increased the participation rate and affected all other factors of globalization linked to the international. China's global role and large-scale trade in the world are important contributors to the spread of the Covid-19 pandemic (Wong, Leo \& Tan, 2020). In addition, the global health and economy, among others, are being hit hard by the Covid-19 pandemic, as it is the boom and the trap of globalization. This global health issue comes with a high degree of uncertainty, such as longer quarantines, travel restrictions, closures of non-essential restaurants and businesses, social remote ordering, lockdowns, and more. regarding the severity, magnitude and extent of the problem. consequences of the Covid-19 pandemic. Thus, global health risks and economic consequences are certainly the consequences of globalization and the entire nation must do everything in its power to address them. Public health crises, infections and diseases, and innovation in therapeutic medicine and vaccines go beyond individuals and their families to involve and influence entire societies, their institutions and their global interrelations and estimations (Kohlscheen, Mojon \& Rees, 2020).

\section{METHODOLOGY OF THE STUDY}

The main purpose of this study is to assess and assess the potential impact of the COVID-19 pandemic on the economy of Bangladesh. This study is based on an empirical overview of recent 
study work, reports, domestic and foreign working papers on the economic crisis. Therefore, the study uses available resources to investigate the potential impact of the 'Covid 19 pandemic and various economic indicators, notably ready-to-wear, remittances abroad, local trade, international trade, government revenues, employment, financial institutions, manufacturing and distributions because of isolation, quarantine, dissociate and shutdown measures in Bangladesh. The study collected most of the review material, exploring the covers of Google Scholar, ProQuest and Scopus, and other online resources, etc.

\section{REVIEW FINDINGS}

\section{Impact of COVID-19 on the economy of Bangladesh}

The COVID-19 has already affected 208 countries and regions in the world. Economically developed countries are failed to tackle this pandemic situation. In comparing developed countries, the developing and poor countries are unable to meet this condition. Bangladesh is the most densely populated country in the world and its medical facilities are so limited that it is not possible to provide medical facilities to large populations. Till now, there is no vaccination for this virus. Only isolation and lockdown are the means to stop the spread of this deadly virus. Due to lockdown and isolation, the world economy is at a turmoil stage. The economy of Bangladesh is seriously affected because of its small number of economic attributes to meet the demand for a huge population. If this lockdown and isolation period continues for a longer period, the people of this nation will die to starve. The possible negative economic impact of COVID-19 covers as under.

\section{Readymade Garments Sector}

The readymade garments sector plays a vital role in the rapidly developing economy of Bangladesh. The readymade garments industries are the principal source of foreign exchange earnings. The readymade garments sector covers more than $85 \%$ of total export earnings. More than four million workers are employed in the RMG industries, and more than $85 \%$ are illiterate women from rural villages (Wikipedia). Due to the commencement of COVID-19, already the Bangladesh readymade garments (RMG) industry has received work order cancellations of nearly $\$ 3$ billion. Around 2 million workers in the industries will be affected by this. Around 4 million people are directly engaged with the RMG sector e.g. backward linkage industries, accessories and packaging factories, and the transportation sector. The government has already declared a Tk-50.00 billion incentive packages to mitigate the losses in the RMG sector. However, if the outbreak prolongs it will be difficult for the government to handle the situation and the result of this will be catastrophic as more than 85 percent of the country's export earnings come through the RMG sector.

\section{Foreign Remittance}

Remittance is the lifeblood of many developing countries in the world like Bangladesh. The country is embraced with a huge population, but this population is assets for the country because they are well known as a remittance fighter and worked in different parts of the world. Bangladesh is now one of the largest recipients of remittance with almost \$15.3 billion in 2018. It was the third-highest recipient of remittance in South Asia in 2018. Bangladesh Bureau of Statistics revealed that $33.45 \%$ of remittances go to investment and $13.74 \%$ of remittances go to savings (Wikipedia). Due COVID-19 pandemic outbreak from January 2020 onwards has seemingly changed many parameters in the world economy, society, politics, and culture. The 
remittance sending behavior, trends, volumes are changing day by day (BMG). However, vulnerability is often higher among migrant workers, and it curbs the capability to send remittances. During the 2008-2009 global financial crisis, we have observed some resilience in remittances flows in certain corridors (Sirkeci et al., 2012). Orozco reported about a 10\% drop in remittances in that period while estimating about a 3\% drop due to the COVID-19 pandemic (Orozco). The lockdowns in many countries will cause migrant workers jobs as well as preventing them to travel back and forth to home countries (Williams., 2020). Remittance flows in 2020 to low- and middle-income countries (LMICs) are projected to fall by 19.7 percent to USD 445 billion, one of the sharpest declines in recent history.

The World Bank projects a decline of remittance flows across all regions: Europe and Central Asia (-27.5\%); Sub-Saharan Africa (-23.1\%), South Asia (-22.1\%), the Middle East and North Africa (-19.6\%), Latin America, and the Caribbean (-19.3\%), and East Asia and the Pacific (-13\%) (World Bank, 2020). The economy largely depends on foreign remittance (Wikipedia). From March to April Due COVID-19 crisis near about 9 million people backed to Bangladesh as a result of the flow of remittance tremendously decreasing in the last few months. The foreign remittance will come down and thus it will hit the foreign reserves of the country. The amount of foreign remittance in July 2019 was Tk. 135.00 billion and each month the flow of remittance declining. The month of March, April, and May 2020 the flow of remittance significantly decreased and at the same time, a large number of people unemployed in abroad, and most of them were backed in the home.

Table 1. Flow of foreign remittance.

(Tk. In billion)

\begin{tabular}{|c|c|c|c|c|c|c|c|c|c|c|c|c|}
\hline Months & $\begin{array}{l}\text { July, } 1 \\
9\end{array}$ & Aug & $\begin{array}{l}\mathrm{Se} \\
\mathrm{pt}\end{array}$ & Oct & $\begin{array}{l}\text { No } \\
\text { V }\end{array}$ & Dec & Jan,20 & Feb & Mar & Apr & May & Jun \\
\hline Amt. & 135 & $\begin{array}{l}122 \\
.08\end{array}$ & $\begin{array}{l}12 \\
4.8\end{array}$ & $\begin{array}{l}13 \\
9\end{array}$ & $\begin{array}{l}13 \\
.85\end{array}$ & $\begin{array}{l}143 \\
.62\end{array}$ & $\begin{array}{l}139 \\
.10\end{array}$ & $\begin{array}{c}123 \\
.36\end{array}$ & $\begin{array}{l}108 \\
.42\end{array}$ & $\begin{array}{l}92 \\
.85\end{array}$ & $\begin{array}{l}127 \\
.82\end{array}$ & $\begin{array}{l}155 \\
.62\end{array}$ \\
\hline
\end{tabular}

Source: Bangladesh Bank

The flow of remittance declined from January 2010 to February 2010 11.29\%, February to March $12.11 \%$, March to April $14.87 \%$. Though the flow of remittance slightly improving in May and June, it does not show a positive sign, if worldwide locked down continued in the next months the flow of remittance will be declined.

\section{Bank and Financial Institutions}

Bangladesh is a developing country with an impoverished banking system with fifty-nine commercial banks, thirty-four non-banking financial institutions, and sixty-two insurance companies (Wikipedia). These institutions are highly interdependent with each other and dependent on the industrial sector of Bangladesh. Due to the outbreak of Covid-19 the banking industry is in critical stages for the mounting of non-performing loans (NPLs). If the RMG industry and its backward linkage industries fail, then the entire banking system will collapse. The commercial banks, non-banking financial institutions, and general insurance companies are heavily relying on garments and related industries for their business. In the long run, the amount of deposit, as well as the investment, will decrease dramatically and these institutions will not 
able to pay enough to its employees. Many employees will lose their job and the number of banks and financial institutions will collapse. The current scenario of non-performing loans indicates horrible situations in the banking sectors. In July 2019 the non -performing loan ratio stood-11.69\%, in October 2019 the ratio was $11.99 \%$, in January 2020 the ratio was $9.30 \%$, and in March the ratio was $9 \%(\mathrm{BB})$.

\section{Food and Agricultures}

Bangladesh is a lower-middle-income country in South Asia, agriculture plays a key role as the main supplier of food, source of livelihood, growth, and employment. Almost half of Bangladeshis are employed in the agriculture sector. During the last decades, the self-sufficiency perspective in rice has become dominant in the food security and agriculture policy (FAO). Since from out-break of Covid-19, various protection measures have been taken by the government of Bangladesh such as border closures, restrictions of movement, closures of restaurants, community quarantines, and market, supply chain, and trade disruptions. As a result, agricultural production, food supply, and demand for the agricultural product have been affected significantly. Farmers are vulnerable as they are hindered from working on their land and accessing markets to sell their products or buy seeds and other essential inputs. There huge shortage of laborers as a result the production and distribution process is now the eve of destruction. The disruptions of the supply chain create frustration among all classes of people. The price hike is now common scenarios because of blockages to transport routes, transport restrictions and quarantine measures, shortages of labor, and spikes in product prices. The supply of fresh foods is now rare and increased levels of food loss and waste. If this situation continues the agricultural sector will face great difficulty.

\section{Local Trade}

The economy of Bangladesh is a developing market economy. It is the $39^{\text {th }}$ largest in the world in nominal terms and $30^{\text {th }}$ largest by purchasing power parity. The country mainly depends on exporting readymade garments items and produces pharmaceutical products, electronics, automobiles, bicycles, leather products, jute-oriented products, paper, plastic, cement, tea, natural gas, etc. (Wikipedia). There is a proverb in investment that never puts all your eggs in a single basket. Bangladesh never obeys this proverb most of the businessmen in this country comfort to investment in the garments industry. If the garment sector collapses the entire economy, there are many backward linkage industries depends on garment industries and many people employed in garment-based industries. Except for garment industries, some large business enterprises operated also facing trouble to import raw material and export finished goods. The sales volume of such industries declining day by day such as steel, cement, plywood, bicycle, metal, gold, hotel, transport, etc. There are many SMEs operated in our country and most of them are controlled over by women are now passing a critical moment the sales volume is now so minimal that these sector fails to meet its operational costs.

\section{Foreign Trade (Export and Import)}

Bangladesh is in Southern Asia, bordering the Bay of Bengal, between Myanmar and India. The country has experienced rapid economic growth in recent years mainly driven by exports of readymade garments and remittance from migrant workers. (intracen.org). The country is largely depended on imported products from neighboring countries. After the outbreak of Covid-19, the import and export-oriented companies are also at risk. The Chattogram Port is the main port in 
Bangladesh. Almost 92 percent of import-export activities are performed through this port, reported that imports and exports through this port declined in March by over 12 percent and 26 percent. Business people fear the country's imports and exports will further decrease in the coming days because of the worsened coronavirus situation. The Chattogram Custom House earns most of its revenue through taxation. According to the Chattogram customs, in March, the country imported goods worth Tk 31,617 crores as per the customs value - about Tk 4,500 crores less than that in the previous month. In the meantime, exports of almost all products, including the top earner ready-made garments fell significantly, too. Compared to those in February, exports in March earned Tk 5,392 crores less. Last month, the country exported goods worth Tk 14,785 crores. Last month, exports of goods, in quantity, were around 21 percent lower than those in February. (Mincom.) The following chart shows the import-export position of the last year in Bangladesh.

Table 2. Flow of exports earning.

(USD in millions)

\begin{tabular}{|l|l|l|l|l|l|l|l|l|l|l|l|l|}
\hline Months & July,19 & Aug & Sept & Oct & Nov & Dec & Jan,20 & Feb & Mar & Apr & May & Jun \\
\hline Amt. & 3581 & 3213 & 3145 & 3711 & 3421 & 3426 & 3617 & 3322 & 2732 & 520 & 1465 & 2714 \\
& .48 & .54 & .58 & .18 & .98 & .11 & .31 & .36 & .00 & .01 & .30 & .95 \\
\hline
\end{tabular}

Source: Bangladesh Bank

Table 3. Flow of imports earning.

(USD in millions)

\begin{tabular}{|l|l|l|l|l|l|l|l|l|l|l|l|l|}
\hline Months & July,19 & Aug & Sept & Oct & Nov & Dec & Jan,20 & Feb & Mar & Apr & May & Jun \\
\hline Amt. & 5247 & 4072 & 5004 & 5279 & 4392 & 5254 & 5334 & 4723 & 4277 & 2858 & 3533 & 4807 \\
& .10 & .70 & .20 & .30 & .40 & .20 & .10 & .70 & .20 & .50 & .40 & .90 \\
\hline
\end{tabular}

Source: Bangladesh Bank

\section{GDP (Gross Domestic Product)}

A huge number of people in Bangladesh live from hand to mouth. The country will fall into a really difficult situation if the country remains locked down for a longer period. Consistent high growth has been unable to create enough jobs in the economy. Due to the inequality of income and asset distribution, the advantages of higher GDP growth are not evident in society. On April 5 , the government unveiled a Tk 72,750 crore stimulus package, including the previously declared Tk 5,000 crore package, to address the economic impacts of the coronavirus outbreak. The amount is nearly 2.52 percent of the country's GDP. According to the forecast released by the Economist Intelligence Unit on 26 March, the global economy is expected to contract by $2.2 \%$ in 2020 . These effects are expected to be more pronounced in major G20 economies, such as Germany, Italy, the United Kingdom, and the US - all countries that are major markets for Bangladesh's most vital tradable good: readymade garments. That is why Bangladesh will face a greater challenge to attain its expected GDP next year. The growth rate of GDP may be declined 
by at least $2.0 \%$ to $2.5 \%$. Recently ADB estimated that the GDP growth of Bangladesh may not exceed $4.5 \%$ this year.

\section{SDGs (Sustainable Development Goal)}

Bangladesh will also face difficulty to attain SDGs goal. The Covid-19 not only impacts in the short-run but also the long-run. The impact on the SDGs could be threefold: First, it will erase some of the commendable achievements made so far regarding some goals which have been directly affected; second, it will slow down the progress of some other goals in the coming months due to resetting of priorities; and third, resources might be reallocated to the immediate priority sectors. All these might cause a delay in the achievement of SDGs; some analysts are even foreseeing a re-evaluation of the timeline for achieving SDGs. As far as the seventeen goals are concerned, the impact can be of two types: explicit and implicit. The goals which are most likely to be explicitly affected are GOAL 1: No Poverty; GOAL 2: Zero Hunger; GOAL 3: Good Health and Well-being; GOAL 4: Quality Education; GOAL 8: Decent Work and Economic Growth; GOAL 10: Reduced Inequality. The forecast mentioned in para-2 is clear indications of that. The goals which might suffer implicitly due to divergence in the priorities are GOAL 5: Gender Equality; GOAL 6: Clean Water and Sanitation; GOAL 7: Affordable and Clean Energy; GOAL 9: Industry, Innovation, and Infrastructure; GOAL 11: Sustainable Cities and Communities; GOAL 13: Climate Action; GOAL 14: Life Below Water; GOAL 15: Life on Land; GOAL 16: Peace and Justice Strong Institutions. Restrictions on worldwide economic activities may lead to some relief for nature, therefore making some improvement relating to SDG no 13, 14, and 15. These, however, may not be enough to compensate substantially for the overall impact.

\section{Government Revenue}

Tax is the principal source of government revenue. The rest of the revenue comes from non-tax sources like fees, charges, tolls, etc. The trend of revenue mobilization for the period from FY2014-15 to FY2018-19 is presented below:

Table 4. Revenue receipt

(Amt. in crore)

\begin{tabular}{|l|l|l|l|l|l|}
\hline Particulars & $2014-2015$ & $2015-2016$ & $2016-2017$ & $2017-2018$ & $2018-2019$ \\
\hline Total Revenue & 163371 & 177400 & 201210 & 259454 & 316599 \\
\hline Tax Revenue & 140676 & 155400 & 178075 & 232202 & 28959 \\
\hline Non-tax Revenue & 22695 & 22000 & 23135 & 27252 & 27000 \\
\hline
\end{tabular}

Source: Bangladesh Economic Review 2019

Government Revenues in Bangladesh increased in 2018-19 income year to 2017-18 income year. Due to the decline in imports and exports, the revenue collection of the government already decreased. Recently the government implements a new income tax policy these may not effective to collect enough tax from the public in a crisis moment. There is no doubt that the revenue receipt will decline in 2019-2020 income year.

\section{Employment}

For that indicator, we provide data for Bangladesh from 1991 to 2019. The average value for Bangladesh during that period was 3.61 percent with a minimum of 2.2 percent in 1991 and a 
maximum of 5 percent in 2009. The latest value from 2019 is 4.19 percent. For comparison, the world average in 2019 based on 182 countries is 7.04 percent. The average for 2019 based on 182 countries was 7.04 percent. The highest value was in South Africa: 28.18 percent and the lowest value was in Qatar: 0.09 percent. The indicator is available from 1991 to 2019. International Labor Organization (ILO) has said the employment rate in Bangladesh and other countries in the region exceeded the global average and was expected to remain so in the coming years because of the government's social protection measures. The regional unemployment rate (in Asia and Pacific countries including Bangladesh) is projected to remain at around 3.6\% until 2020, below the global average, the ILO said in its World Employment and Social Outlook: Trends 2019 (WESO), released recently, reports BSS. It said the global average of the unemployment rate was 5.6\% while the figure was around 3.6\% in Bangladesh and the other Asia and Pacific nations. ILO attributed Bangladesh's better employment scenario to significant social protection measures while the countries with higher poverty rates lacked such measures. From the above data and predication of ILO, it seems that Bangladesh may not face a critical situation in the COID-19 pandemic. But the scenarios are different a large number of people already lost their jobs, salaries of the employees cut down significantly, employees lacked in job security, deprived of fair payment, increasing frustration among employees, increasing job shifting, a huge number of workers moved to agricultural sectors, child labor increased day by day, decreasing better quality jobs, work environment deteriorating day by day. It should be very difficult for Bangladesh to meet the Sustainable Development Goals (SDGs) by 2030. It needs to ramp up its efforts on improving social protection, skills training, and occupational safety and health. Bangladesh needs to create millions of decent and sustainable jobs each year if it wants to reduce poverty and reach middle-income status.

\section{SUMMARIZATION OF REVIEW FINDINGS}

Undeniably, the COVID-19 pandemic is taking an unprecedented toll on global economy along with public health and livelihood issues. As in the case of each of pillars of the economy of Bangladesh are sternly battered and consequently it will take times to get back usual pace in economic activities. The readymade garments industries, the biggest export earnings sector, are highly shaken due to isolation, lockdown, travel ban, and supply chain disruption worldwide. For the betterment of the RMG sectors, the government already declared a stimulus package. Government, immediately, should take comprehensive support plan until this crisis removes to make this sector sustainable. The government may diversify the export basket, not depends on RMG sectors, because RMG earn lion part of its total export earnings. Moreover, the effects of COVID-19 pandemic on the agrarian economic growth of Bangladesh witness a shocking slow down and Farmers, workers; entrepreneurs related to agro-based products are likely to challenge an irreparable loss and identity crisis. The agro sector of Bangladesh has a good impact on the country's gross domestic product (GDP). As such, authorities need to provide adequate financial, logistic and motivational supports so that they might keep courage and reinvest in their workplaces accordingly. Bangladesh government has taken some practical initiatives and announced incentive packages of Tk. 50,000 million for providing financial support for the farmers in the rural areas for boosting up agricultural production.

Furthermore, the millions of Bangladeshi skilled and unskilled remittance earners working worldwide severely impacted (i.e. about 0.50 million of workers returned to Bangladesh) by the COVID-19 pandemic for draconian movement control measure, lockdown, travel ban, and factory closure. Authorities need give financial support for these returned 
expatriates workers and make them engage in production or entrepreneurial activities. To ensure a smooth flow of foreign remittance in future government may implement various strategies e.g. ensure export of human resources with safety and security by government agencies, searching for new labor markets, improving diplomatic relationships with importers countries, ensure compensatory packages for wage earners.

Alike other sectors, the pandemic hardly stunned the money market and stock market for work station closure and deteriorated the financial health of the both market. Along with above, Micro, Small and medium scale enterprise (MSME) or backward linkage enterprises is seriously affected by supply chain disruption, lockdown, and factory closure. Many the workforces of Bangladesh are engaged in informal sector are mostly affected alongside formal sector employees due to the COVID-19 pandemic. Social safety programs such as the Vulnerable Group Feeding and Vulnerable Group Development for the next years must be extended by the government to keep the livelihood of layman sustainable. As Bangladesh is the fastest growing developing country, Its Gross Domestic Products (GDP) Annual Development Program (ADP), Fiscal Policy, and Sustainable Development Goal (SDG) are profoundly hampered by the COVID-19 pandemic. Furthermore, the magnitude of the economic losses will depend on how the outbreak evolves as any pandemic diseases and its economic consequences are vastly ambiguous which makes it challenging for policymakers to work out an axiomatic and appropriate macroeconomic policy guideline. So, effective policies, initiatives, coordination and awareness buildup are inevitable to avert the severity of the crises to overcome this pandemic, and an unprecedented wake-up call and coordinated efforts are inevitable governments, and private organizations.

\section{CONCLUSIONS AND RECOMMENDATIONS}

Since from outbreak of Covid-19 at Wuhan, China as on December 1, 2019, now spread the whole globe with devastating mode. Every part of the world is now panicked to tackle contagious diseases. We already face an economic slowdown not only in third world countries but also in first world countries. It is assumed if such situations continue there might be a recession in the long term. Like other developing counties Bangladesh will fall a great difficulty because this country largely depends on foreign remittance and exporting readymade garments. There is many remittance fighters moved in Bangladesh and the exportation of human power is stopped. The exportation of readymade garments declined day by day. A huge number of the population is now unemployed and increasing depression among this unemployed. It is still unknown when the devastating manner of Covid-19 will end, so all arms of government and other agencies should take effective policies, initiatives, coordination and awareness buildup to avert the severity of the crises and be proactive in soothing possible negative impacts in near future.

The study also revealed that the magnitude of the economic losses will depend on how the outbreak evolves as any pandemic diseases and its economic consequences are vastly ambiguous which makes it challenging for policymakers to work out an axiomatic and appropriate macroeconomic policy guideline. Therefore, right and effective policies, initiatives, coordination and awareness buildup are inevitable to avert the severity of the crises to overcome this pandemic, and an unprecedented wake-up call and coordinated efforts are inevitable governments, and private organizations. Finally, the study suggested that as Covid-19 still surfacing all over the world so some steps should be ensured by the government agencies of Bangladesh to mitigate possible threats for the economy. 


\section{REFERENCES}

Ali, M. J., Bhuiyan, A. B., Zulkifli, N., \& Hassan, M. K. (2020). The Covid-19 Pandemic: Conceptual Model for the Global Economic Impacts and Recovery. Available at SSRN: https://ssrn.com/abstract=3656243. doi:http://dx.doi.org/10.2139/ssrn.3656243

Baldwin, R., Weder, B., \& Mauro, D. (n.d.). Economics in the Time of COVID-19. In primo-europe.eu. Retrieved May 1, 2020, from www.cepr.org

Guerrieri, V., Lorenzoni, G., Straub, L., \& Werning, H. I. (2020). Macroeconomic Implications of COVID-19: Can Negative Supply Shocks Cause Demand Shortages? https://www.nber.org/papers/w26918

Islam, M. S., Irana Ira, J., Ariful Kabir, K. M., \& Kamrujjaman, M. (2020). COVID-19 Epidemic Compartments Model and Bangladesh. https://doi.org/10.20944/preprints202004.0193.v1

Islam, M. T., Kumar Talukder, A., Siddiqui, N., Islam, T., \& Islam, M. T. (2020). Tackling the Pandemic COVID-19: the Bangladesh Perspective. https://doi.org/10.20944/preprints202004.0384.v1

Ma, Y., Zhao, Y., Liu, J., He, X., Wang, B., Fu, S., Yan, J., Niu, J., \& Luo, B. (2020). Effects of temperature variation and humidity on the mortality of COVID-19 in Wuhan. Medrxiv.Org. https://doi.org/10.1101/2020.03.15.20036426

Reger, M. A., Stanley, I. H., \& Joiner, T. E. (2020). Suicide Mortality and Coronavirus Disease 2019 - A Perfect Storm? In JAMA Psychiatry. American Medical Association. https://doi.org/10.1001/jamapsychiatry.2020.1060

Rodela, T., Tasnim, S., Mazumder, H., \& Faizah, F. (2020). Economic Impacts of Coronavirus Disease (COVID-19) in Developing Countries. https://osf.io/preprints/socarxiv/wygpk/

Sumner, A., Hoy, C., \& Ortiz-Juarez, E. (2020). WIDER Working Paper 2020/43-Estimates of the impact of COVID-19 on global poverty. Indiaenvironmentportal.Org.In. https://doi.org/10.35188/UNU-WIDER/2020/800-9

Toda, A. A. (2020). Susceptible-Infected-Recovered (SIR) Dynamics of COVID-19 and Economic Impact. http://arxiv.org/abs/2003.11221

Business Media Georgia. Available at: https://bm.ge/en/article/on-the-background-of-coronavirusremittances-up-in-georgia--statistics-/51189

Sirkeci, I., Cohen, J. H., \& Ratha, D. (Eds.). (2012). Migration and Remittances During the Global Financial Crisis and Beyond. Washington, DC: The World Bank.

Orozco, Manuel (2020). Migrants and the Impact of the COVID-19 Pandemic on Remittances, available at: https://www.lac.ox.ac.uk/sites/default/files/lac/documents/media/2020_article _on_migrants _and_the_impact_of_covid 19_on_remittances.pdf?time $=1584982389407$ [Accessed: $10 / 04 / 2020]$

Williams, A. (2020). Coronavirus will hit economies across all EBRD regions, available at:https://www.ebrd.com/news/2020/-coronavirus-will-hit-economies-across-all-ebrd-regions

www. wikipedia.com

www.fao.org

www.intracen.org

www.mincom.gov.bd

\section{Copyrights}

Copyright for this article is retained by the author(s), with first publication rights granted to the journal. This is an open-access article distributed under the terms and conditions of the Creative Commons Attribution license (http://creativecommons.org/licenses/by/4.0/) 